\title{
Phenol Removal from Palm Oil Mill Effluent Using Galactomyces reessii Termite-Associated Yeast
}

\author{
Pimprapa Chaijak ${ }^{1 *}$, Monthon Lertworapreecha ${ }^{2}$, Chontisa Sukkasem ${ }^{3}$ \\ ${ }^{1}$ Department of Biotechnology, Thaksin University, Phatthalung 93210, Thailand \\ ${ }^{2}$ Department of Microbiology, Thaksin University, Phatthalung 93210, Thailand \\ ${ }^{3}$ Department of Food Science and Technology, Phatthalung 93210, Thailand
}

Received: 7 February 2017

Accepted: 21 June 2017

\begin{abstract}
Lignin-modifying enzymes have long been used in palm oil mill effluent (POME) treatment to remove the dark brown colour resulting from phenolic contamination. This study investigated a cost-effective industrial application method for optimizing phenol removal from POME using the termite-associated yeast Galactomyces reessii obtained from the subterranean termite under laboratory conditions. The yeast was cultured in POME, and the activity of the ligninolytic enzymes (laccase and manganese peroxidase) was monitored by spectrophotometry. Optimal conditions were achieved using a Box-Behnken experimental design. Results demonstrated that G. reessii reduced the phenolic compounds in POME by $88.69 \%$ with growth in $100 \%$ (v/v) POME using $30 \%(\mathrm{w} / \mathrm{v})$ consortia and $5 \%(\mathrm{w} / \mathrm{v})$ calcium carbonate $\left(\mathrm{CaCO}_{3}\right)$ at room temperature $30 \pm 1^{\circ} \mathrm{C}$ for seven days. G. reessii showed high performance for phenolic removal and decolourization of POME and other industrial wastewaters.
\end{abstract}

Keywords: optimization, palm oil mii effluent, phenolic compound, termite-associated yeast, Box-Behnken design

\section{Introduction}

The global situation in the decrease of fossil fuels and other non-renewable energy sources is now of significant concern. Interest in renewable energy is increasing from this situation. The oil palm (Elaeis guineen L.) is known as a sustainable energy source for biodiesel production. It is more versatile than other oil crops and provides a higher yield for less energy input [9]. Highly colored palm oil mill effluent (POME) generates approximately $60 \%$ of global

*e-mail: chaijak.pimprapa@gmail.com crude palm oil [10]. Today the oil palm is an important economic crop in southern Thailand, and in 2016 oil palm plantations covered an area of 720,000 ha. A recent report by the National Science and Technology Development Agency (NSTDA) indicated that Thai agriculturists produced 9 million tons per year of fresh fruit bunches (FFB), with 0.19 tons of POME released from every ton of FFB. Consequently, around 1.026 million tons of darkcolored POME was produced annually. Raw POME is a highly polluting wastewater containing $95-96 \%$ colloidal suspensions, $4-5 \%$ total solids, and $0.6-0.7 \%$ palm oil. The oxidation of phenolic compounds such as lignin and anaerobically degraded products result in the dark 
brown color of POME [7]. Treatment of POME always uses aerobic and anaerobic bacteria. This system can decrease high biological oxygen demand (BOD) from the wastewater, but does not remove the dark brown color. Thus, physical and chemical procedures have been attempted to resolve this problem, but this method has a higher cost per unit volume of wastewater treated than the use of biological systems [10-12].

Lignin-modifying enzymes such as laccase (EC 1.10.3.2) and manganese peroxidase (EC 1.11.1.13) are well-known oxidoreductases used in the decolorization of industrial paper mill and palm oil mill effluents [15]. Laccases are blue multi-copper oxidases that catalyze the monoelectronic oxidation of a broad spectrum of substrates, including diphenols, polyphenols, aminophenols, and amines through a four-electron reduction of oxygen $\left(\mathrm{O}_{2}\right)$ to water $\left(\mathrm{H}_{2} \mathrm{O}\right)$. Multi-copper oxidases are capable of degrading lignin and these are abundant in many white-rot fungi [17]. All wooddecaying fungi - including the white-rot fungi Trametes versicolor, Pleurotus ostreatus, Xylaria sp., and the termite-associated fungus Termitomyces sp. - show high potential of lignin-modifying enzyme production $[1,2,5$, 16]. Symbiotic yeasts play an essential role through plant material fermentation in the hindgut of subterranean termites. The two yeast strains, Debaryomyces hansenii and Sporothrix albicans, were found in the hindgut of the lower termites Mastotermes darwiniensis, Zootermopsis angusticollis, Zootermopsis nevadensis, Neotermes jouteli, Reticulitermes santonensis, and Heterotermes indicola [14].

Our recent study focuses on the subterranean termiteassociated yeast Galactomyces reessii from para rubber plantations in southern Thailand and reported on its lignin-modifying enzyme activity. The symbiotic yeast was screened for phenol removal activity. We found that the ligninolytic yeast had high ability for phenol removal in POME [3]. In this work, the optimal conditions of phenol removal in POME were investigated using the BoxBehnken experimental design. The ligninolytic yeast was monitored for its phenolic removal and decolourization potential of POME using spectrophotometry.

\section{Experimental}

\section{Microorganism and Culture Conditions}

The ligninolytic yeast G. reessii was obtained for our laboratory on Phatthalung Campus at Thaksin University in southern Thailand. The culture was maintained on malt extract agar (MEA; $20 \mathrm{~g} / \mathrm{L}$ of malt extract, $20 \mathrm{~g} / \mathrm{L}$ of dextrose monohydrate, $6 \mathrm{~g} / \mathrm{L}$ of peptone, and $18 \mathrm{~g} / \mathrm{L}$ of agar) supplement with $50 \mathrm{~g} / \mathrm{L}$ of chloramphenicol to avoid bacterial contamination until required for use. For consortium preparation, the yeast on MEA was bored by a cork borer ( $4.0 \mathrm{~mm}$ i.d.). The culture plug was transferred in malt extract broth (MEB) supplement and incubated at $30 \pm 1^{\circ} \mathrm{C}$ for five days with $150 \mathrm{rpm}$ shaking.

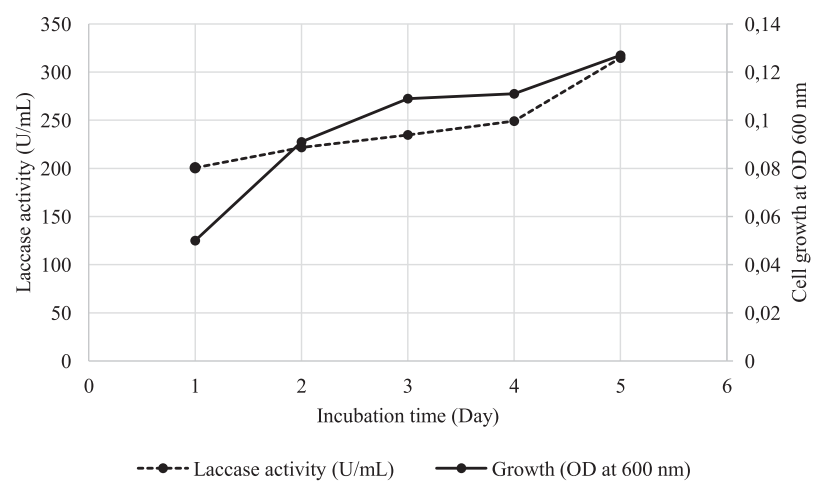

Fig. 1. Growing of Galactomyces reessii in raw POME and its laccase activity $(\mathrm{U} / \mathrm{mL})$.

\section{POME Source}

The rich phenol-contaminating POME was collected from an oil palm plantation in Trang Province of southern Thailand in June 2016. The dark wastewater was collected in a $50 \mathrm{~mL}$ sterile plastic bottle then transferred to our laboratory and stored at $4 \pm 1^{\circ} \mathrm{C}$ until required for use.

\section{POME Preparation}

The POME was filled through a $0.25 \mu \mathrm{m}$ Whatman paper filter to remove the suspended particles and contaminating microorganisms. The filtered POME was then placed in $250 \mathrm{~mL}$ Erlenmeyer flasks for further study.

\section{Monitoring Culture Growing in POME}

The cultures were transferred into $250 \mathrm{~mL}$ sterile Erlenmeyer flasks containing $90 \mathrm{~mL}$ of filtered POME and sterilized at $121 \pm 1^{\circ} \mathrm{C}$ for $15 \mathrm{~min}$. The POME was inoculated with $10 \mathrm{~mL}$ of consortium. After that, growth and ligninolytic activity were monitored. The cultures were grown at $30 \pm 1^{\circ} \mathrm{C}$ with shaking at $150 \mathrm{rpm}$ for five days, then the samples were collected every $24 \mathrm{~h}$ for five days. Yeast cell growth performance was determined by spectrophotometry at $600 \mathrm{~nm}$. Growth curves were plotted as absorbance vs. time to monitor enzyme activity

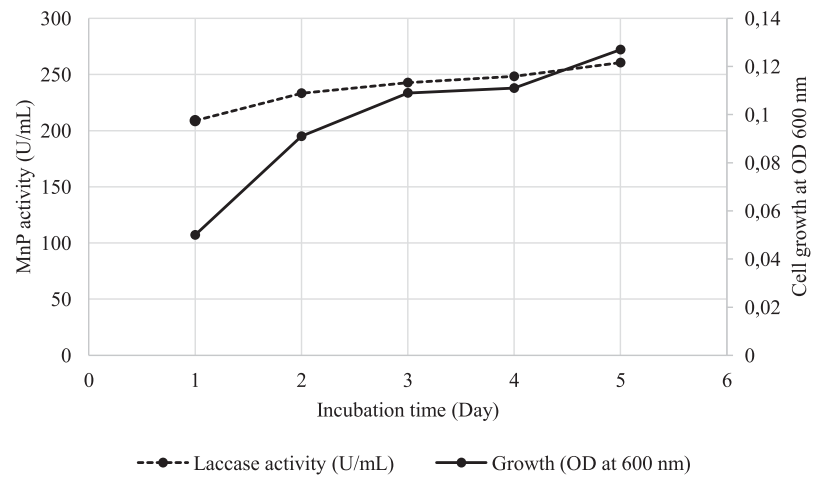

Fig. 2. Growing of Galactomyces reessii in raw POME and its manganese peroxidase $(\mathrm{MnP})$ activity $(\mathrm{U} / \mathrm{mL})$. 


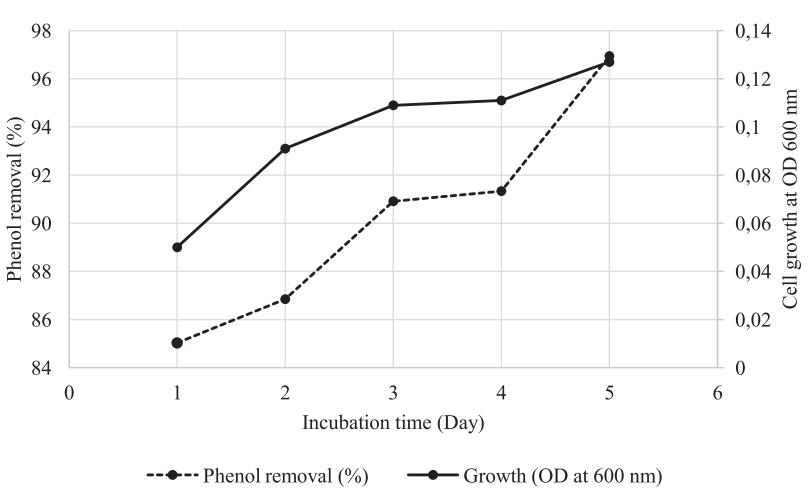

Fig. 3. Growing of Galactomyces reessii in raw POME and phenol removal (\%).

and decreasing total phenol contamination. The cultures were centrifuged at $9,000 \mathrm{~g}$ for $10 \mathrm{mins}$ to remove the yeast cells. The supernatants were filtered through filter paper and stored at $4 \pm 1^{\circ} \mathrm{C}$ for further study. Determining total phenol content was performed following the FolinCiocalteu method. In short, $0.5 \mathrm{~mL}$ of POME was diluted with $4.5 \mathrm{~mL}$ of distilled water, and $5 \mathrm{~mL}$ of Folin-Ciocalteu reagent was added. After five minutes, $5 \mathrm{~mL}$ of $10 \%$ sodium carbonate $\left(\mathrm{Na}_{2} \mathrm{CO}_{3}\right)$ solution was added and the mixture was briefly incubated and then cooled. The absorbance of the reaction was monitored at $760 \mathrm{~nm}$. Total phenol was calculated by gallic acid equivalent [4]. Laccase (Lac) activity was determined at $420 \mathrm{~nm}$ using ABTS (2,2'-Azino-bis(3ethylbenzothiazoline-6-sulphonic acid) as a substrate. The assay mixture contained $1 \mathrm{mM}$ ABTS in $100 \mathrm{mM}$ sodium acetate buffer $(\mathrm{pH}$ 3.6) mixed with $10 \mu \mathrm{L}$ aliquots of crude enzyme in a total volume of $200 \mu \mathrm{L}$ [1]. Manganese peroxidase (MnP) activity was estimated by spectrophotometry at $415 \mathrm{~nm}$ using ABTS as a substrate. One unit of enzyme activity was defined as the amount of enzyme required to produce $1 \mu$ mole of oxidized ABTS per minute.

\section{Experimental Design}

Optimizing phenol removal in raw POME was performed by $G$. reessii. The experimental design followed the Box-Behnken method. Cultural conditions were screened for four factors as incubation time (day),

Table 1. Factors and levels of each factor used for phenol removal.

\begin{tabular}{|c|c|c|c|}
\hline \multirow{2}{*}{ Factor } & \multicolumn{3}{|c|}{ Level } \\
\cline { 2 - 4 } & -1 & 0 & 1 \\
\hline Incubation times (days) & 4 & 7 & 10 \\
\hline POME concentrations (\%) & 80 & 90 & 100 \\
\hline Culture concentration (\%) & 10 & 20 & 30 \\
\hline $\mathrm{CaCO}_{3}$ & 1 & 5 & 10 \\
\hline
\end{tabular}

Table 2. Box-Benhken design for phenol removal by Galactomyces reessii.

\begin{tabular}{|c|c|c|c|c|}
\hline $\begin{array}{l}\text { Run } \\
\text { order }\end{array}$ & $\begin{array}{c}\text { Incubation } \\
\text { times } \\
\text { (days) }\end{array}$ & $\begin{array}{c}\text { POME } \\
\text { concentrations } \\
(\%)\end{array}$ & $\begin{array}{c}\text { Culture } \\
\text { concentrations } \\
(\%)\end{array}$ & $\begin{array}{c}\mathrm{CaCO}_{3} \\
(\%)\end{array}$ \\
\hline 1 & 4 & 100 & 20 & 5 \\
\hline 2 & 7 & 90 & 20 & 5 \\
\hline 3 & 7 & 90 & 30 & 10 \\
\hline 4 & 10 & 90 & 30 & 5 \\
\hline 5 & 4 & 80 & 20 & 5 \\
\hline 6 & 7 & 90 & 10 & 10 \\
\hline 7 & 4 & 90 & 10 & 5 \\
\hline 8 & 4 & 90 & 20 & 10 \\
\hline 9 & 7 & 80 & 30 & 5 \\
\hline 10 & 4 & 90 & 30 & 5 \\
\hline 11 & 7 & 90 & 20 & 5 \\
\hline 12 & 7 & 90 & 10 & 1 \\
\hline 13 & 7 & 100 & 30 & 5 \\
\hline 14 & 7 & 100 & 20 & 1 \\
\hline 15 & 7 & 80 & 10 & 5 \\
\hline 16 & 7 & 100 & 20 & 10 \\
\hline 17 & 10 & 90 & 20 & 1 \\
\hline 18 & 10 & 100 & 20 & 5 \\
\hline 19 & 7 & 100 & 10 & 5 \\
\hline 20 & 10 & 80 & 20 & 5 \\
\hline 21 & 4 & 90 & 20 & 1 \\
\hline 22 & 7 & 80 & 20 & 1 \\
\hline 23 & 7 & 90 & 30 & 1 \\
\hline 24 & 7 & 90 & 20 & 5 \\
\hline 25 & 7 & 80 & 20 & 10 \\
\hline 26 & 10 & 90 & 10 & 5 \\
\hline 27 & 10 & 90 & 20 & 10 \\
\hline
\end{tabular}

POME concentration (\%), culture concentration (\%), and $\mathrm{CaCO}_{3}(\%)$. The filtered raw POME was used as the wastewater sample. All treatments were carried out in $250 \mathrm{~mL}$ Erlenmeyer flasks covered with sterile cotton and aluminium foil under aerobic conditions at $30 \pm 1^{\circ} \mathrm{C}$ with shaking.

\section{Statistical Analysis}

Statistical data were performed by regression and ANOVA analysis at a 95\% confidence level using Minitab ${ }^{\circledR}$ version 17.00 for Windows (Minitab, Pennsylvania, USA). 
Table 3. Phenol removal in raw POME by Galactomyces reessii.

\begin{tabular}{|c|c|c|c|c|c|}
\hline Treatment & $\begin{array}{l}\text { Incubation times } \\
\text { (days) }\end{array}$ & $\begin{array}{c}\text { POME concentrations } \\
(\%)\end{array}$ & $\begin{array}{c}\text { Culture } \\
\text { concentrations (\%) }\end{array}$ & $\begin{array}{c}\mathrm{CaCO}_{3} \\
(\%)\end{array}$ & $\begin{array}{c}\text { Phenol removal } \\
(\%)\end{array}$ \\
\hline 1 & 4 & 100 & 20 & 5 & 84.460 \\
\hline 2 & 7 & 90 & 20 & 5 & 81.891 \\
\hline 3 & 7 & 90 & 30 & 10 & 79.051 \\
\hline 4 & 10 & 90 & 30 & 5 & 83.442 \\
\hline 5 & 4 & 80 & 20 & 5 & 66.524 \\
\hline 6 & 7 & 90 & 10 & 10 & 85.303 \\
\hline 7 & 4 & 90 & 10 & 5 & 76.850 \\
\hline 8 & 4 & 90 & 20 & 10 & 82.666 \\
\hline 9 & 7 & 80 & 30 & 5 & 80.405 \\
\hline 10 & 4 & 90 & 30 & 5 & 84.683 \\
\hline 11 & 7 & 90 & 20 & 5 & 82.098 \\
\hline 12 & 7 & 90 & 10 & 1 & 83.597 \\
\hline 13 & 7 & 100 & 30 & 5 & 88.669 \\
\hline 14 & 7 & 100 & 20 & 1 & 83.057 \\
\hline 15 & 7 & 80 & 10 & 5 & 81.251 \\
\hline 16 & 7 & 100 & 20 & 10 & 85.723 \\
\hline 17 & 10 & 90 & 20 & 1 & 87.940 \\
\hline 18 & 10 & 100 & 20 & 5 & 85.302 \\
\hline 19 & 7 & 100 & 10 & 5 & 85.303 \\
\hline 20 & 10 & 80 & 20 & 5 & 79.389 \\
\hline 21 & 4 & 90 & 20 & 1 & 82.977 \\
\hline 22 & 7 & 80 & 20 & 1 & 79.220 \\
\hline 23 & 7 & 90 & 30 & 1 & 87.474 \\
\hline 24 & 7 & 90 & 20 & 5 & 85.822 \\
\hline 25 & 7 & 80 & 20 & 10 & 82.944 \\
\hline 26 & 10 & 90 & 10 & 5 & 83.132 \\
\hline 27 & 10 & 90 & 20 & 10 & 80.913 \\
\hline
\end{tabular}

\section{Results and Discussion}

\section{Growth in Raw POME}

The analysis of autoclaved POME showed total phenolic compounds at $0.832 \mathrm{mg} / \mathrm{mL}$. Growth ability, ligninolytic enzyme production, and phenol removal were monitored by spectrophotometry. After inoculation in POME, the culture was monitored for growth potential in the toxic wastewater. For ligninolytic enzyme production, data showed that $G$. reessii yeast produced laccase at 200.683, 221.843, 234.812, 249.147, and $314.676 \mathrm{U} / \mathrm{mL}$ after incubation at $30 \pm 1^{\circ} \mathrm{C}$ under aerobic conditions with shaking for $1,2,3,4$, and 5 days of incubation, respectively (Fig. 1). Moreover, G. reessii secreted manganese peroxidase at 208.889, 223.333, $242.778,248.333$, and $260.556 \mathrm{U} / \mathrm{mL}$ over $1-5$ days (Fig. 2).

Contaminated polyphenol content decreased with ligninolytic enzyme activity of the culture at 85.023, 86.847, 90.915, 91.336, and 96.947\% after incubation under the same conditions (Fig. 3). On the other hand, Neoh et al. 2013 [10] used the filamentous fungi Aspergillus fumigatus isolated from POME sludge for the POME treatment, but they found the A. fumigatus successfully grown in POME supplemented with $5.7 \mathrm{~g} / \mathrm{L}$ of glucose. Kietwanboot et al. 2015 [8] have been reported about the phenolics and colour removal activities in the white rot fungi Trametes hirsute strain AK04 that was found to be more tolerant of high POME concentration. 
Table 4. Multiple regressions and significant terms $(\mathrm{p}<0.05)$.

\begin{tabular}{|c|c|c|c|c|c|c|}
\hline Source & DF & SS & MS & F-Value & P-Value & Remark \\
\hline Regression & 4 & 202.010984 & 50.502746 & 4.03 & 0.0133 & Significant \\
\hline CaCO $_{3}$ & 1 & 3.589428 & 3.589428 & 0.29 & 0.5977 & ---- \\
\hline Culture (\%) & 1 & 5.724245 & 5.724245 & 0.46 & 0.5060 & ---- \\
\hline POME (\%) & 1 & 152.517830 & 152.517830 & 12.18 & 0.0021 & Significant \\
\hline Times (Days) & 1 & 40.179480 & 40.179480 & 3.21 & 0.0870 & ---- \\
\hline Residual error & 22 & 275.467641 & 12.521256 & ----- & ---- & ---- \\
\hline Lack-of-fit & 20 & 265.679712 & 13.283986 & 2.71 & 0.3036 & ---- \\
\hline Pure error & 2 & 9.787929 & 4.893964 & ----- & ---- & ---- \\
\hline Total & 26 & 477.478625 & ---- & ---- & --- & ---- \\
\hline
\end{tabular}

This system improved the fungal dephenolization and decolorization up to $82.2 \pm 3.8 \%$ and $87.1 \pm 1.1 \%$ after eight days of incubation. Moreover, Elmi et al. 2015 [6] applied microbial fuel cell (MFC) technology for POME treatment. The bacteria Pseudomonas aeruginosa NCIM 5223 was cultured in MFC anode under anaerobic conditions. The results showed $58 \%$ of chemical oxygen demand (COD) removal and $60 \%$ of color removal over eight days, while Othman et al. 2014 [13] treated the high phenol-contaminated POME by chemical method. In their work, the $10 \mathrm{~g} / \mathrm{L}$ of activated carbon and $0.6 \mathrm{~g} / \mathrm{L}$ of polyaluminium chloride were applied into the POME for wastewater treatment. Thus, G. reessii in our work showed high ability and efficiency for POME treatment, but needed low cost per volume of wastewater.

\section{Optimization of Phenol Removal}

The experimental design followed the Box-Behnken method. Cultural conditions were screened for four factors, including incubation time (day), POME concentration (\%), culture concentration (\%), and $\mathrm{CaCO}_{3}(\%)$ at three levels for each factor (Table 1) in 27 experiments (Table 2). Maximal phenol removal was determined at $100 \%$ POME concentration, 30\% culture concentration, $5 \% \mathrm{CaCo}_{3}$, and seven days incubation time, when the culture removed $88.669 \%$ of the phenolic compounds (Table 3). Optimal treatment conditions regarding culture growth and ligninolytic enzyme production were determined at $228.333 \mathrm{U} / \mathrm{mL}$ manganese peroxidase and $255.973 \mathrm{U} / \mathrm{mL}$ laccase.

\section{Statistical Analysis}

Regression analysis was assessed using Minitab version 17.00 for Windows (Minitab, Pennsylvania, USA). Statistical analysis of the Box-Behnken design demonstrated regression values of $p<0.05$, indicating that the model was significant (Table 4). Regression analysis was performed on the results. A first-order polynomial equation was derived representing phenol removal as a function of the independent variables. The regression equation of phenol removal was represented as:

$$
\begin{gathered}
\text { Phenol removal }(\%)=45.492-0.1211 \mathrm{CaCO}_{3} \\
(\%)+0.0691 \text { Culture }(\%)+0.3565 \mathrm{POME}(\%) \\
+0.6099 \text { Time (Days) }
\end{gathered}
$$

\section{Conclusions}

This study revealed significant knowledge regarding the extracellular ligninolytic activity of termiteassociated yeasts and their roles in phenol removal from POME. Results indicated that G. reessii had potential as an efficient strain for phenol removal in POME based on extracellular enzymes, including laccase and manganese peroxidase. Research regarding optimal conditions indicated seven days of incubation time, 30\% culture concentration, and $5 \% \mathrm{CaCO}_{3}$ as the most suitable for contaminated phenol treatment in non-diluted raw POME. Knowledge gained from these studies can be utilised for the development of cost-effective wastewater treatment systems for effective phenol removal from POME.

\section{Acknowledgements}

We are thankful to Ms. Sumontha Sa-nguankhiao and Ms. Sirilak Noomee for our sample collection, and we acknowledge financial support from the Science Achievement Scholarship of Thailand.

\section{References}

1. BERTRAND B., MARTINEZ-MORALES F., TINOCOVALENCIA R., ROJAS S., ACOSTA-URDAPILLETA L., TREJO-HERNANDEZ R.M. Biochemical and molecular characterization of laccaes isoforms produced by the white-rot fungus Trametes versicolor under submerged culture conditions. J. Mol. Catal. B: Enzym., 122, 339, 2015. 
2. CASTANO J.D., CRUZ C., TORRES E. Optimization of the production, purification and characterization of a laccase from the native fungus Xylaria sp. Biocatal. Agric. Biotechnol., 4 (4), 710, 2015.

3. CHAIJAK P., LERTWORAPREECHA M., SUKKASEM C. Decolorization and phenol removal of palm oil mill effluent by termite-associated yeast. International journal of Biological, Agricultural, Food and Biotechnological Engineering, 11 (1), 29, 2017.

4. DUTTA B., MAHANTA B. Studies on secondary metabolites total phenol and flavonoid contents of Eupatorium cannabinum L. in Assam, India. J. Med. Plants., 4 (2), 130, 2016.

5. EL-BATAL A.I., ELKENAWY N.M., YASSIN A.S., AMIN M.A. Laccase production by Pleurotus ostreatus and its application in synthesis of gold nanoparticles. Biotechnol. Rep., 5, 31, 2015.

6. ELMI H.S.A., NOR M.H.M., IBRAHIM Z. Colour and COD Removal from Palm Oil Mill Effluent (POME) Using Pseudomonas Aeruginosa Strain NCIM 5223 in Microbial Fuel Cell. Int. J. Waste Resour., 5 (3), 1, 2015.

7. IGWE J.C., ONYEGBADO C.O., ABIA A.A. Studies on the kinetics and intraparticle diffusivities of BOD, colour and TSS reduction from palm oil mill effluent (POME) using boiler fly ash. Afr. J. Environ. Sci. Technol., 4 (6), 392, 2010.

8. KIETKWANBOOT A., TRAN H.T.M., SUTTINUN O. Simultaneous Dephenolization and Decolorization of Treated Palm Oil Mill Effluent by Oil Palm FiberImmobilized Trametes hirsuta Strain AK 04. Water Air Soil Pollut., 226 (10), 345, 2015.

9. MEKHILEF S., SIGA S., SAIDUR R. A review on palm oil biodiesel as a source of renewable fuel. Renewable and Sustainable Energy Reviews, 15 (4), 1937, 2011.

10. MOHAMMED R.R. Decolorisation of Biologically Treated Palm Oil Mill Effluent (POME) Using Adsorption Technique. IRJES., 2 (10), 1, 2013.
11. NEOH C.H., LAM C.Y., LIM C.K., YAHYA A., IBRAHIM Z. Decolorization of palm oil mill effluent using growing cultures of Curvularia clavata. Environ. Sci. Pollut. Res., 21 (6), 4397, 2014.

12. NEOH C.H., YAHYA A., ADNAN R., MAJID Z.A., IBRAHIM Z. Optimization of decolorization of palm oil mill effluent (POME) by growing cultures of Aspergillus fumigatus using response surface methodology. Environ. Sci. Pollut. Res., 20 (5), 2912, 2013.

13. OTHMAN A.S., HASSAN M.A., SHIRAI Y., BAHARUDDIN A.S., ALI A.A.M., IDRIS J. Treatment of effluents from palm oil mill process to achieve river water quality for reuse as recycled water in a zero emission system. J. Clean Prod., 67, 58, 2014.

14. PRILLINGER H., MESSNEG R., KONIG H., BAUER R., LOPANDIC K., MOLNAR O., DENGEL P., WEIGANG F., KIRISITS T., NAKASE T., SIGLER L. Yeast associated with termites: A phenotypic and genotypic characterization and use of coevolution for dating evolutionary radiations in Asco- and basidiomycetes. Appl. Environ. Microbiol., 19, $265,1996$.

15. SAHOO D.K., GUPTA R. Evaluation of ligninolytic microorganisms for efficient decolorization of a small pulp and paper mill effluent. Process. Biochem., 40 (5), 1573, 2005.

16. TAPRAB Y., JOHJIMA T., MAEDA Y., MORIYA S., TRAKULNALAEMSAI S., NOPARATNARAPORN N., OHKUMA M. KUDO T. Symbiotic fungi produce laccases potentially involved in phenol degradation in fungus combs of fungus-growing termites in Thailand. Appl. Environ. Microbiol., 71 (12), 7696, 2005.

17. VISWANATH B., RAJESH B., JANARDHAN A., KUMMAR A.P., NARASIMHA G. Fungal laccases and their application in bioremediation. Enzyme Res., 2014, 1, 2014. 